\title{
Enrichment of bacterial DNA for the diagnosis of blood stream infections
}

\author{
Ngo Tat Trung ${ }^{1,7}$, Tran Thi Thu Hien', Tran Thi Thanh Huyen', Dao Thanh Quyen', Trinh Van Son ${ }^{2,7}$, \\ Phan Quoc Hoan ${ }^{1}$, Nguyen Thi Kim Phuong ${ }^{3}$, Tran Thi Lien ${ }^{4}$, Mai Thanh Binh ${ }^{5,7}$, Hoang Van Tong ${ }^{6,7}$, \\ Christian G. Meyer ${ }^{6,7}$, Thirumalaisamy P. Velavan ${ }^{6,7^{*}}$ and Le Huu Song ${ }^{1,2,7^{*}}$
}

\begin{abstract}
Background: Blood cultures are commonly employed to identify bacterial pathogens causing sepsis. PCR assays to diagnose septicemia require extraction of bacterial DNA from blood samples and thus, delay the initiation of appropriate antimicrobial treatment. The presence of abundant human DNA may hamper the sensitivity of PCR in the detection of bacteria.

Methods: We used serial dilutions of E. Coli spiked pseudo-blood-sepsis samples to develop a simple method that combines the use of a polar detergent solvent and adjustment of the basic pH to remove human DNA. A 16S rRNA gene-based screening algorithm was established to differentiate Gram-positive and Gram-negative groups of bacteria and the family of Enterobacteriaceae. A stringent validation with appropriate controls was implemented. The method of human DNA removal was then applied on 194 sepsis blood samples and 44 cerebrospinal fluid (CSF) samples by real-time PCR.
\end{abstract}

Results: This uncomplicated and straightforward approach allows to remove up to $98 \%$ of human DNA from peripheral blood of septic patients. The inhibitory effect of human DNA is efficiently prevented and the detection limit of real-time PCR is increased to $10 \mathrm{E}$. Coli CFUs/ml. This sensitivity is 10 times higher compared to conventional real-time PCR assays. The classical blood culture detected 58/194 (30 \%) of sepsis and 9/44 (21 \%) of CSF samples. Out of the 194 blood samples tested, the conventional real-time PCR targeting 13 common sepsis causing pathogens correctly detected the bacterial DNA in 16/194 (8\%) only and 14/44 (32\%) in cerebrospinal fluid samples. Our newly established approach was able to provide correct diagnoses in 78 (40\%) of the 194 blood samples and in 14 (32\%) of the CSF samples. The combination of both blood cultures and our technique raised the rate of sepsis diagnoses to 112/194 (58 \%). Of the total group tested positive, 46 (24\%) cases showed overlap with the classical methodology.

Conclusion: We report a simple optimized in-house protocol for removal of human DNA from blood sepsis samples as a pre-analytical tool to prepare DNA for subsequent PCR assays. With the detection increase of our in-house DNA removal approach, subsequent PCR assays can reach detection limits of 10 E. coli CFUs/ml and significantly improve the diagnostic rate in blood sepsis cases.

Keywords: Sepsis, Bloodstream infection, Human DNA removal, Molecular diagnosis, Blood culture

\footnotetext{
* Correspondence: velavan@medizin.uni-tuebingen.de; lehuusong@108-icid.

com

Thirumalaisamy P. Velavan and Le Huu Song are shared senior authors.

${ }^{6}$ Institute of Tropical Medicine, University of Tübingen, Tübingen, Germany

${ }^{1}$ Department of Molecular Biology, 108 Military Central Hospital, Hanoi,

Vietnam

Full list of author information is available at the end of the article
}

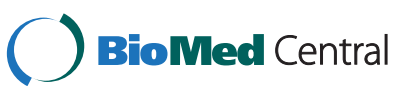

(c) 2016 The Author(s). Open Access This article is distributed under the terms of the Creative Commons Attribution 4.0 International License (http://creativecommons.org/licenses/by/4.0/), which permits unrestricted use, distribution, and reproduction in any medium, provided you give appropriate credit to the original author(s) and the source, provide a link to the Creative Commons license, and indicate if changes were made. The Creative Commons Public Domain Dedication waiver (http://creativecommons.org/publicdomain/zero/1.0/) applies to the data made available in this article, unless otherwise stated. 


\section{Background}

Even after the development of new diagnostic and therapeutic techniques, the physiopathology of sepsis is still poorly understood; incidences and mortality are steadily increasing. Delayed diagnosis usually results in multiorgan failure and with frequent fatal outcomes [1]. Timely and appropriate diagnoses of bloodstream infections (BSI) have a significant and measurable impact on patient care and infection control in resource-limited settings [2]. Although the classical blood culture is widely accepted as a gold standard it still has various drawbacks. For instance, blood cultures are time-consuming and can only detect bacteria growing on suitable media used. A minimum volume of $30 \mathrm{ml}$ of blood is required for each aerobic and anaerobic bacterial cultures [3]; such amounts are challenges particularly for old and neonatal patients. A rapid diagnostic method applicable under clinical conditions and complementing classical blood cultures is therefore essential.

The polymerase chain reaction (PCR) has provided new possibilities for rapid detection of bacterial pathogens in patients with sepsis [2]. In addition, the multiple-priming format (multiplex) PCR allows rapid detection of various microbial pathogens in a shorter period of time. Although many advancements in molecular diagnostics of bacterial pathogens have been achieved $[4,5]$, PCR based diagnoses of BSI are still difficult. A most critical factor is that PCR assays may fail to amplify sparse copies of pathogens in the abundance of human DNA. In addition, PCRinhibitory compounds in human blood can considerably reduce the sensitivity of an assay. For instance, a typical BSI case has a bacterial density of $1-1000 \mathrm{CFU} / \mathrm{ml}$ in their peripheral blood [6]. An optimized PCR reaction can only amplify the 16S rRNA target if the bacterial load exceeds $1000 \mathrm{CFU} / \mathrm{ml}$. Thus, PCR assays may be ineffectual in replicating blood culture results $[7,8]$. The diversity of bacterial strains further complicates optimized conditions for multiplex PCR reactions.

During evolution, the fusion of two prokaryotic genomes (e.g., Archae and Proteobacteria) has resulted in the formation of a eukaryotic genome with sufficient horizontal gene transfer $[9,10]$. This indicates that the possibility of the presence of homologous and/or conserved DNA sequences between human and bacterial genomes exists, possibly causing primer mispairing and consequently leading to false positive results. Commercial molecular diagnostic tests such as the SepsiTest (Molzym), and VYOO (SIRS Lab) apply various approaches to deplete human genomic DNA prior to the molecular diagnosis [7, 11-14]. In these molecular assays, either DNAses cleaving human DNA or methylated chromatography columns are used to remove human DNA. Larger volumes of human blood are recommended in these assays. Since such kits are costly, low-income countries can frequently not afford them.
We developed a simple in-house method that combines the use of a polar detergent solvent and adjustment of basic $\mathrm{pH}$ to remove human DNA. We also utilized a $16 \mathrm{~S}$ rRNA based real-time PCR screening algorithm to differentiate Gram-positive and Gram-negative bacteria as well as the family of Enterobacteriaceae. Our newly developed procedure was validated in 194 peripheral blood samples obtained from septic patients with likely abundant human DNA and 44 samples of cerebrospinal fluid (CSF) with sparse human DNA. The diagnostic performance of i) the classical blood culture approach (arm-1), ii) conventional real-time PCR screening using total DNA extracted from patients samples (arm-2), and iii) our real-time PCR screening approach using templates depleted of human DNA (arm-3) were compared.

\section{Methods}

Ethics statement

The study was submitted for regulatory approval to the institutional review board of the 108 hospital and was approved. Following submission, the Ethical Committee of the 108 Military Central Hospital, Hanoi has provided consent and ethical approval for the study was duly obtained. Informed written consent was obtained from all study patients and/or from their parents if the study participant was under 18 years of age.

\section{Dilution series formulation}

The E. coli DH5 alpha strain (Invitrogen, Singapore) was inoculated into liquid LB medium for proliferation until reaching the $\log$ phase. A dilution series from $10000 \mathrm{CFU} / \mathrm{mL}$ to $1 \mathrm{CFU} / \mathrm{mL}$ until eventual negativity was done to spike the bacteria into $5 \mathrm{~mL}$ of human blood. The spiked bacteria in blood were then used for the procedure of human DNA depletion and subsequent isolation of bacterial DNA. DNA extracted from single colonies of Klebsiella pneumoniae, Proteus mirabilis, Neisseria meningitidis, Salmonella spp., Pseudomonas aeruginosa, Acinetobacter baumannii, Staphylococcus aureus, S. epidermidis, Streptococcus pneumoniae, S. suis and Enterococcus spp. were reconstituted in $200 \mu \mathrm{l}$ of $25 \mathrm{mM}$ Tris-EDTA at $\mathrm{pH} 8$ containing $100 \mathrm{ng} / \mu \mathrm{l}$ human DNA extracted from full blood; $5 \mu \mathrm{l}$ of these solutions were used as positive controls for all PCR or real-time PCR reactions.

\section{Depletion of human DNA and bacterial DNA isolation}

Several detergents including non-ionic (NP-40, Triton-X 100), ionic (CTAB, SDS) and zwitterionic (CHAPS) detergents were screened. Only Triton-X 100 was able to lyse mammalian cell membranes, but not those of $E$. coli. Triton-X 100 was, therefore, considered for further analyses. Different conditions such as variation in $\mathrm{pH}$, time, and $\mathrm{Na}_{2} \mathrm{CO}_{2}$ concentrations were also optimized (Additional file 1: Table S1). Mammalian cell lysis 
buffers MCLB-1 was used to treat the pseudo-sepsis samples by mixing volumes of $1.2 \mathrm{ml}$ blood from healthy donors (spiked with 100,000 E. coli cells) with $1.2 \mathrm{ml}$ solvent. After solvent treatment, the suspensions were centrifuged to collect bacterial pellets for subsequent $\mathrm{NaOH} / \mathrm{SDS}$ total DNA extraction. Residuals of human DNA and intactness of spiked E. coli genome were examined and quantified by RT-PCR (Additional file 1: Figures S1 and S2).

Overnight-grown $E$. coli were spiked in peripheral venous blood samples obtained from healthy donors to establish dilution serials of $1000 \mathrm{CFU} / \mathrm{ml}, 100 \mathrm{CFU} / \mathrm{ml}$, $10 \mathrm{CFU} / \mathrm{ml}, 1 \mathrm{CFU} / \mathrm{ml}$ and $0 \mathrm{CFU} / \mathrm{ml}$ (negative control). The dilution serials were separated into two groups. The first group was subjected to human DNA removal by mixing thoroughly with an equal volume of mammalian cell lysis buffer (MCLB-1, containing $2 \mathrm{M} \mathrm{Na}_{2} \mathrm{CO}_{2}$ $\mathrm{pH}$ 9.8, 1 \% Triton-X100) for three minutes at ambient temperature to allow for complete fragmentation of human chromatin into DNA fragments. After the incubation step an equal volume of neutralization buffer (1 M Tris- $\mathrm{HCl}, \mathrm{pH} 4.5$ ) was added in order to prevent further cell lysis. The samples were then centrifuged at $5000 \mathrm{~g}$ for $5 \mathrm{~min}$. The supernatants were discarded and bacterial pellets were resuscitated in $200 \mu \mathrm{l}$ of $1 \mathrm{x}$ phosphate buffered saline (PBS) and used for isolation of bacterial DNA by a conventional method using the $\mathrm{NaOH} / \mathrm{SDS}$ approach [15]. The second group of the dilution serials also underwent conventional DNA extraction using the $\mathrm{NaOH} / \mathrm{SDS}$ approach [15].

The integrity of spiked E. coli genomic DNA and the presence of residual human DNA was measured by $E$. coli specific primers/probe (Additional file 1: Tables S2 and S3) real-time PCR or SYBR green based real-time PCR using the beta globin-specific primers: BetaF: 5'AGA AGA GCC AAG GAC AGG TAC G-3', BetaR: 5'TGC TAG TGA ACA CAG TTG TGT CAG A-3'.

\section{Reagent preparation under aseptic conditions}

Primers and labeled probes (Integrated DNA Technologies, Singapore) used are listed in Additional file 1: Tables S2 and S3. All primers and probes were available in stocks of $100 \mathrm{pmol} / \mu \mathrm{l}$ in $25 \mathrm{mM}$ Tris- $\mathrm{HCl}$ and treated with $1 \mathrm{U}$ DNase $/ 20 \mu \mathrm{l}$ reaction volume for $15 \mathrm{~min}$ at $37{ }^{\circ} \mathrm{C}$. Subsequently, the DNAse was inactivated by heating at $95{ }^{\circ} \mathrm{C}$ for $40 \mathrm{~min}$. After inactivation, the stock was aliquoted into volumes of $10 \mu \mathrm{l}$ and stored at $-20{ }^{\circ} \mathrm{C}$ [16]. For decontamination of the PCR mastermix, 8methoxypsoralen was dissolved in dimethylsulfoxide (DMSO) (Sigma, Germany). For decontamination of PCR water and the real-time PCR mastermix reagents, $25 \mu \mathrm{g} /$ $\mathrm{mL}$ of 8-methoxypsoralen (Sigma, Germany) and $10 \mathrm{~min}$ exposure to $366 \mathrm{~nm}$ UV irradiation over a distance of $3 \mathrm{~cm}$ were applied. The MCLB-1 buffer was also decontaminated by UV irradiation at $280 \mathrm{~nm}$ over a distance shorter than $5 \mathrm{~cm} \mathrm{[16].} \mathrm{Working} \mathrm{places} \mathrm{and} \mathrm{all} \mathrm{ac-}$ cessories and tools in our laboratory are decontaminated weekly by spraying with DNA-ExitusPlus ${ }^{\text {Tw }}$ solution (AppliChem, Germany).

\section{Real-time PCR conditions}

The real-time PCR assay mixtures consisted of $7.5 \mu \mathrm{l}$ Taqman real-time PCR Master Mix (Qiagen, Hilden, Germany), $5 \mu \mathrm{l}$ DNA template, 5 pmol of primers and $0.2 \mathrm{pmol}$ of probe. The reaction was run in the Stratagene M3000p (Stratagene, USA) device with a preincubation step at $50{ }^{\circ} \mathrm{C}$ for $15 \mathrm{~min}$, initial denaturation at $95{ }^{\circ} \mathrm{C}$ for $5 \mathrm{~min}$, followed by 45 cycles of $95^{\circ} \mathrm{C}$ for $15 \mathrm{~s}$ and $60^{\circ} \mathrm{C}$ for $60 \mathrm{~s}$. The first real-time PCR assay differentiates Gramnegative, Gram-positive and Enterobacteriacea bacteria. The second assay discriminates the distinct bacterial species using primers and Taqman probes specific for the 13 most common pathogens, namely Staphylococus aureus, S. epidermidis, Streptococcus pneumoniae, S. suis, Enterococcus spp. (Gram-positive bacteria) and Escherichia coli, Klebsiella pneumoniae, Proteus mirabilis, Salmonella spp., Neisseria meningitidis, Pseudomonas aeruginos, and Acinetobacter baumannii (Gram-negative bacteria).

\section{Sepsis patients and blood sampling}

A total of 194 peripheral venous blood and 44 CSF from septic patients were available at the 108 Military Central Hospital, Hanoi, Vietnam. Samples were collected between February 2014 and September 2015. Diagnoses of sepsis were confirmed by physicians, based on a body temperature above $38.3^{\circ} \mathrm{C}$ or below $36{ }^{\circ} \mathrm{C}$, heart rate $>90$ beats per minute, respiratory rate higher than 20 breaths per minute, an assumed or confirmed infection with at least one of the following signs and symptoms: significantly decreased urine output, abrupt change in consciousness/mental status, decreased platelet count, difficulty of breathing, abnormal heart pumping function, or abdominal pain [17]. Blood and CSF samples from all patients were preserved in heparinized tubes. Prior to the analyses specimens were stored at $4{ }^{\circ} \mathrm{C}$.

In order to compare diagnostic techniques in the identification of pathogens causing sepsis, $10 \mathrm{ml}$ of venous blood or $0.5 \mathrm{ml}$ CSF were collected in duplicates from all patients and divided into equal portions for the detection of aerobic bacteria. The blood samples were subjected to automatic bacterial culture, and CSF was used for conventional bacterial cultures. In parallel, $2.4 \mathrm{ml}$ blood or $1 \mathrm{ml}$ of CSF were equally partitioned into one sample $(1.2 \mathrm{ml}$ blood or $0.5 \mathrm{ml} \mathrm{CSF})$ that was used directly for total DNA extraction, and a second sample (1.2 ml blood or $0.5 \mathrm{ml}$ CSF) which was used for MCLB-1 treatment to remove human DNA prior to 
extraction of bacterial DNA. DNA isolated from samples treated with MCLB-1 was used for screening to discriminate Gram-negative, Gram-positive and Enterobacteriacea bacteria. Samples positive in the screening step were then subjected to group-specific real-time PCR assays to identify and confirm infection by 13 common pathogens causing sepsis as mentioned above (Fig. 1a).

\section{Automated bacterial culture}

Twenty ml blood were collected per patient and aliquoted in $10 \mathrm{ml}$ tubes for culturing in the BD BACTEC $\mathrm{C}^{\mathrm{mm}}$ 9120 blood culture system at $36{ }^{\circ} \mathrm{C} \pm 0.5$ for 48 h until growth in both tubes was observed (Becton Dickinson, New Jersey, USA). After $24 \mathrm{~h}$ of incubation, identification of bacterial species was performed using the VITEK $^{\circ} 2$ automated system (BioMérieux, France).

\section{Conventional bacterial culture}

To establish diagnostic techniques for the examination of CSF samples, we followed protocols provided by the Manual of Clinical Microbiology [18] and the CDC Laboratory Methods for the Diagnosis of Meningitis [19]. Briefly, $600 \mu \mathrm{l}$ aliquots of CSF from each patient was vortexed in $600 \mu \mathrm{l}$ PBS. The resulting suspension was streaked onto four media, namely blood agar, MacConkey agar, chocolate agar and buffered charcoalyeast extract agar (BCYE) and incubated under aerobic conditions at $37{ }^{\circ} \mathrm{C}$ for three days. Colonial growth was asserted and confirmed by microbiologists.

\section{Results}

Efficiency of human DNA removal

Utilization of mammalian cell lysis buffer (MCLB-1) resulted in removal of $98 \%$ human DNA, obviously without affecting bacterial DNA (Fig. 2a). Our data reveal that, at a high density of spiked bacteria (>1000 CFU/ml), human DNA does not impede the downstream PCR. However, at lower bacterial loads $(<100 \mathrm{CFU} / \mathrm{ml})$ human DNA inhibits subsequent PCR reactions (Fig. 2b, Table 1, Additional file 1: Figure S3). Efficient removal of inhibitory effects caused by human DNA increased the detection limits of the PCR to $10 \mathrm{CFU} / \mathrm{ml}$, a detection limit which conventional PCR assays could not reach (Fig. 2, Table 1). The discrimination of Gram-positive and Gramnegative bacteria as well as Enterobacteriacea requires four hours only, with two additional hours of the real-time PCR assay to identify bacterial species (Fig. 1b).

\section{Limit of detection}

In order to determine the concentration of spiked E. coli at which the real-time PCR assay can detect bacterial DNA and the cut-off concentration at which the PCR cannot distinguish spiked bacterial DNA from precontaminated microbial DNA, we grew E. coli and spiked it in blood samples from healthy donors to establish 20 dilution serials of $1000 \mathrm{CFU} / \mathrm{ml}, 100 \mathrm{CFU} / \mathrm{ml}, 10 \mathrm{CFU} / \mathrm{ml}$, $1 \mathrm{CFU} / \mathrm{ml}$ and $0 \mathrm{CFU} / \mathrm{ml}$ (negative control). These were equally divided into several aliquots to allow independent technical assistants to conduct MCLB-1-based removal of human DNA and DNA extraction. Bacterial DNA was

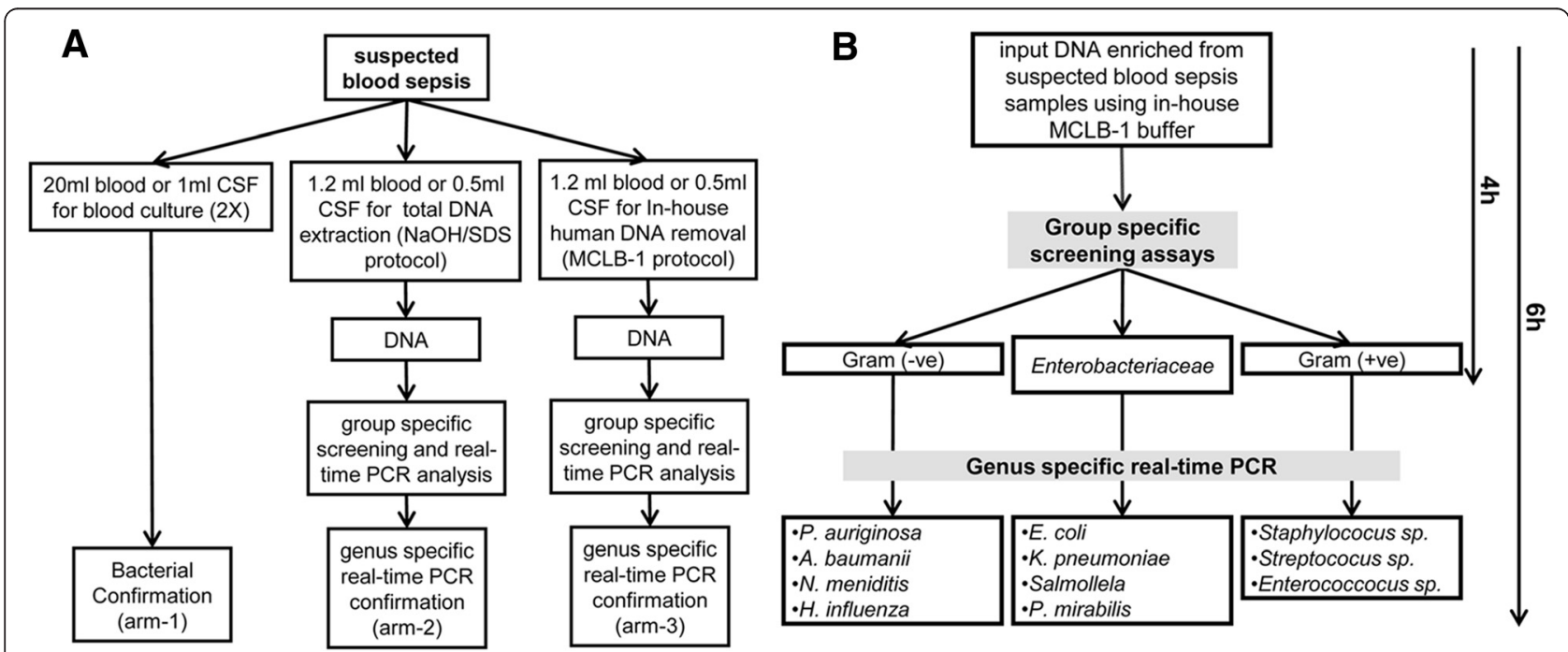

Fig. 1 Work flow of the established protocol for human DNA removal. a Study flowchart to compare sepsis causing pathogen diagnoses by PCR and blood culture. $\mathbf{b}$ Group-specific screening by PCR reactions targeting bacterial 16SrRNA gene to differentiate Gram-positive, Gram-negative and Enterobacteriaceae groups. Samples positive in the screening assay were subjected to genus-specific real-time PCR reactions to detect 13 most common sepsis causative pathogens 

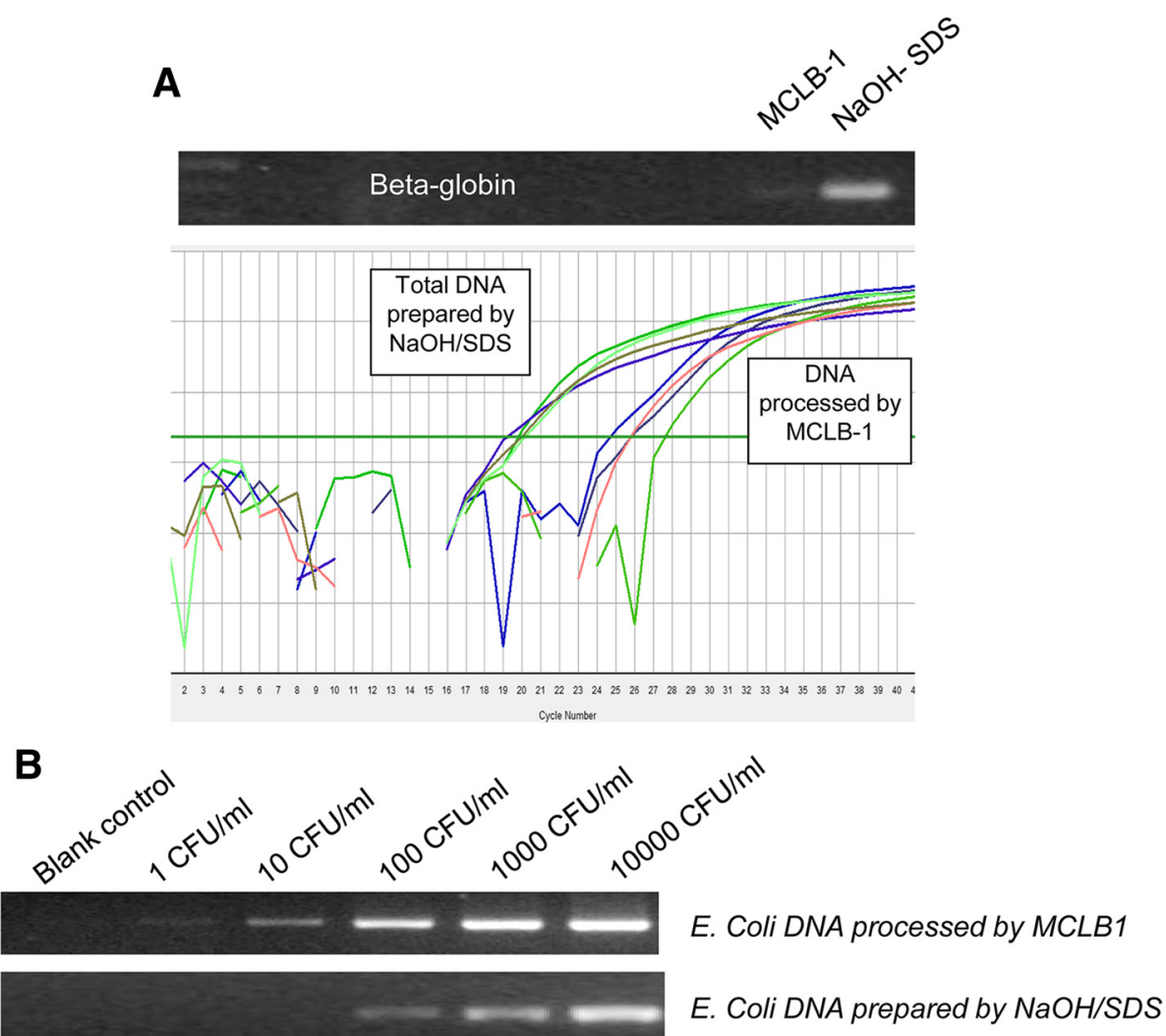

Fig. 2 Efficiency of human DNA removal and sensitivity of PCR assay. a Residues of human DNA after MCLB-1 treatment were monitored via beta-globin derived amplification assays. Upper panel gel based PCR assay targeting the beta-globin gene; lower panel is SYBR green based real-time PCR to quantify residual beta-globin gene fragments. b Detection limits of spiked E. coli at various densities. At high density of spiked bacteria (1000 CFU/ml or 10000 CFU/ml), removal of human DNA does not provide a significant diagnostic signal, but at low concentration (100 CFU/ml or $10 \mathrm{CFU})$, removal of human DNA enhances detection limit of the diagnostics PCR to $10 \mathrm{CFU} / \mathrm{ml}$

used as template for real-time PCR using primers and probes specific for Enterobacteriaceae and E. coli. RTPCR could detect spiked E. coli at concentrations of $100-1000 \mathrm{CFU} / \mathrm{ml}$ with a $\mathrm{Ct}$ value of $29.2 \pm 0.5$ at $1000 \mathrm{CFU} / \mathrm{ml}$ and of $34.5 \pm 0.5$ at $100 \mathrm{CFU} / \mathrm{ml}$ (Table 2, Additional file 1: Figure S4). In addition, the real-time PCR could still detect 14 out of 20 cases with Ct values of $37 \pm 1$ at a concentration of $10 \mathrm{CFU} / \mathrm{ml}$. However, the real-time PCR could only detect 7 out of 20 with Ct values of $42 \pm 1.3$ at a concentration of $1 \mathrm{CFU} / \mathrm{ml}$. These results indicate that our real-time PCR procedure was not able to distinguish samples with spiked bacteria at a concentration of $1 \mathrm{CFU} / \mathrm{ml}$ from pre-contaminated bacterial DNA. Therefore, for practical purposes, we set a cut-off of $10 \mathrm{CFU} / \mathrm{ml}$, corresponding to a $\mathrm{Ct}$ value of 37 for all pathogens under investigation.

\section{Comparison of blood culture versus molecular identification of pathogens}

The advantage of human DNA removal prior to PCR diagnosis by treatment with MCLB-1 was validated by using 194 blood samples and 44 CSF samples from septic patients. The samples were divided into three arms, arm 1 for blood culture, arm 2 for direct $\mathrm{NaOH} / \mathrm{SDS}$ DNA extraction and conventional RT-PCR analysis and arm 3 for MCLB-1 treatment and subsequent RT-PCR detection. Among 44 CSF samples, where human DNA might be present in small amounts only, conventional PCR and the PCR assays with previous MCLB-1 treatment provided identical results (14/44 positive cases). The detection rate by PCR was higher than that obtained by blood culture, which detected bacterial DNA in 9 of the 44 CSF samples only (Fig. 3). However, all

Table 1 Ct value of spiked E. coli dilution series upon in-house human DNA removal step

\begin{tabular}{llllll}
\hline E. coli density (CFU/ml) & 1000 & 100 & 10 & 1 & 0 \\
\hline MCLB1 processed DNA & $29.2 \pm 0.5$ & $34 \pm 0.5$ & $37 \pm 1$ & Undetectable $^{(a)}$ & Undetectable $^{(a)}$ \\
NaOH/SDS processed DNA & $29.0 \pm 0.5$ & $37 \pm 1$ & Undetectable $^{(a)}$ & Undetectable $^{(a)}$ & Undetectable $^{(a)}$
\end{tabular}

(a) Undetectable means that the real-time PCR fluorescent signal appears later than that of cut-off assays (see the detection limits and negative control validation) 
Table 2 Detection limits and frequency of detection of spiked E. coli dilution series upon in-house human DNA removal step

\begin{tabular}{llllll}
\hline $\begin{array}{l}\text { Spiked E coli density } \\
\text { (CFU/ml) }\end{array}$ & 1000 & 100 & 10 & 1 & 0 \\
\hline Average detected Ct & $29.2 \pm 0.5$ & $34 \pm 0.5$ & $37 \pm 1$ & $42 \pm 1.3$ & $42 \pm 1.3$ \\
Frequency of detection & $20 / 20$ & $20 / 20$ & $14 / 20$ & $7 / 20$ & $6 / 20$ \\
\hline
\end{tabular}

positive samples identified by conventional PCR could be confirmed by MCLB-1-processed real-time PCR in the 194 blood samples (Fig. 4). Furthermore, the conventional approach could detect 16 of the 194 samples only, indicating a low power detection rate than that obtained by the MCLB-1-based approach. These results clearly show that efficient removal of human DNA from septicemic blood samples provides a considerable advantage and facilitates PCR diagnoses.

Out of the 194 blood samples obtained from septic patients, 58 (30\%) were positive by blood culture (arm 1), of which 15 (8\%) were positive for other species, namely Enterobacter sakazaki (1 case), L. monocytogenes (2 cases), Alcaligenes. faecalis (1 case), Pseudomonas. fluorescens (3 cases), Stenotrophomonas. maltophilia (1 case case) and Candida albicans (1 case), Enterobacter. aerogenes (1 case), Morganella. morganii (2 cases), Burkholderia. pseudomallei (1 case), Candida. tropicalis (1 case) and Burkholderia. cepacia (1 case) (Fig. 4a). The in-house real-time PCR methodology using MCLB-1-processed DNA (arm 3) detected 78 (40 \%) of 194 BSI samples. The combination of blood culture with MCLB-1-based real-time PCR methods could increase the sensitivity up to $58 \%$ (112 positive cases). We observed that 46 out of 112 positive cases ( $41 \%$ of positive cases, or
$24 \%$ of the total blood samples) were correctly identified between blood culture and MCLB-1 based realtime PCR. Of the 46,24 ( $21 \%$ of the positive cases or $12 \%$ of the total blood samples) were identified between the two methods at species level (Fig. 4a, b, Additional file 1: Figure S5).

\section{Discussion}

Our dilution series have shown a strong inhibitory effect of human DNA on subsequent PCR assays targeting bacteria. Once human DNA is removed efficiently from venous blood samples, the detection limit of real-time PCR is enhanced more than ten times. Although removal of human DNA does not improve subsequent PCR detection in samples with low human DNA content such as in CSF, it significantly enhances the diagnostic success of samples with human DNA abundance in septic blood samples.

Bacteremia accounts for a high risk of mortality, both in industrialized and in resource-limited settings [1]. Our genus-specific real-time PCR assays, together with the in-house protocol for removal of human DNA not only provides faster diagnoses, but also increases the sensitivity and specificity in the detection of pathogens compared to culture techniques.

Blood cultures are considered the gold standard for the diagnosis of bacterial or fungal BSI [2]. This method provides results after $24-48 \mathrm{~h}$ or even a longer period of time, and a tailored therapy can then be adapted based on the presumptive bacterial identification. This method is time consuming with a minimum of 24 to $48 \mathrm{~h}$ and treatment options may be compromised

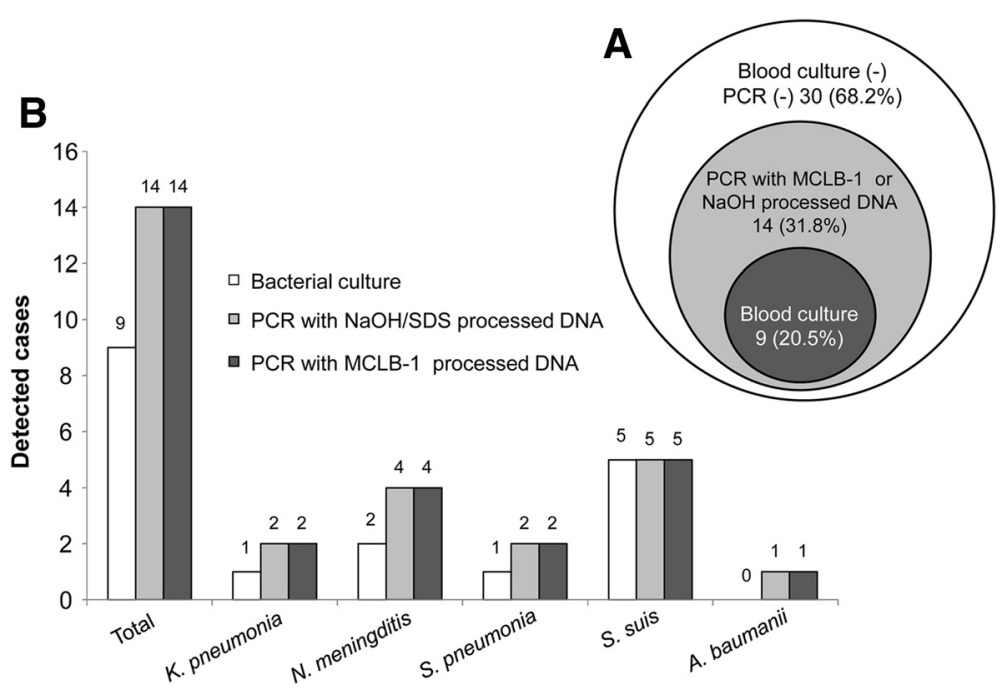

Fig. 3 Comparison of diagnostic methodologies for sepsis causing pathogens in CSF samples. a Venn diagram shows the diagnostic overlap of the blood culture approach (dark gray - arm 1), real-time PCR using conventional NaOH DNA extraction approach (light gray - arm 2) and real-time PCR using DNA removed DNA (light gray - arm 3). b The diagnostic performance are illustrated for classical blood culture (gray bars), conventional real-time PCR with total human DNA (black bar) and real-time PCR algorithm using MCLB1 treated samples with depleted human DNA 


\section{A}

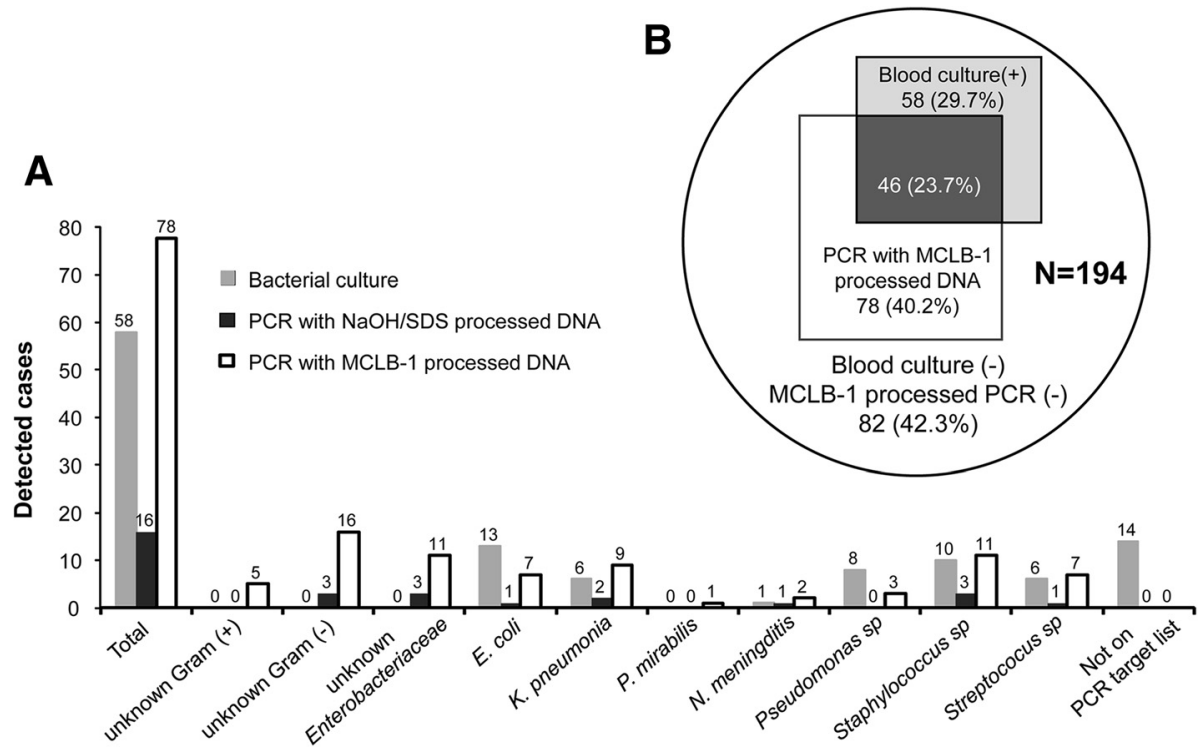

Fig. 4 Comparison of diagnostic methodologies for sepsis causative pathogens in human abundance sepsis samples. a Venn diagram shows the overlap between PCR using human DNA removed input samples - arm 3 and blood culture method - arm1. $\mathbf{b}$ The detailed diagnostic performance is illustrated for classical blood culture method (gray bars) or conventional real-time PCR approach using DNA extracted from total human blood sepsis samples (black bar) or real-time PCR using algorithm using MCLB-1 treated samples

severely. Early detection and adequate treatment of BSI are mandatory within the first $6-12 \mathrm{~h}[20,21]$. The development of rapid diagnostic methods for BSI is important in order to supplement conventional blood culture diagnostics [2]. Nucleic acid-based diagnostic approaches have the potential to address this need [3, 4]. However, the low amount of copies of pathogen DNA and the presence of PCR-inhibitory compounds in blood, including the presence of human DNA, remain challenges $[5,11,22]$.

The combination of a mild detergent (MCLB-1, containing $2 \mathrm{M} \mathrm{Na}_{2} \mathrm{CO}_{2} \mathrm{pH}$ 9.8, 1 \% Triton-X100) applied for 3 min results in removal of approximately $98 \%$ of human DNA from full blood samples. Processing of bacterial DNA prior to molecular detection requires only a short time, which does not cause significant damage of bacterial DNA. In addition, in the presence of a mild detergent, human blood cells are disrupted efficiently to release human DNA. This does not apply to bacterial and fungal cells. An elevated basic pH $9.8 \mathrm{Na}_{2} \mathrm{CO}_{3-}$ sodium carbonate) ensures successful degradation of human DNA. Thus, intact bacteria and fungi from blood are enriched. Nevertheless, the selective lysis reaction needs to be controlled over time as bacterial cell walls might be lysed upon prolonged exposure.

Current commercial DNA removal kits such as MolYsis Basic (MolZym GmbH \& Co. KG, Bremen, Germany) and Looxster (SIRS-lab GmbH, Jena, Germany) work with high blood volumes and require methylated chromatographic columns or DNAses that are patented. Due to significant costs, these kits are commonly not available in low income communities.

Treatment of sepsis usually depends on the presumptive bacterial identification, suggested by Gram staining or/and group specificity of bacteria [23]. Our procedure is a systematic approach, with a stepwise process initiated by real-time PCR reactions to identify Gram-negative, Grampositive and Enterobacteriacea bacteria. If a patient sample is positive for any group of pathogens, strain-specific Taqman real-time PCR assays are indicated. The diagnostic procedure can be completed within four hours, not only rapidly providing accurate results, but also significantly reducing the cost compared to individual PCR reactions for a large number of pathogens.

In our study and recommended for clinical practice we set a cut-off value of $10 \mathrm{CFU} / \mathrm{ml}$. This limit of detection excludes positive results for patients who are infected with bacterial loads lower than $10 \mathrm{CFU} / \mathrm{ml}$. This explains in part the fact that our molecular method could not recapitulate the positive cases revealed by blood culture. On the other hand, in patients already treated with antibiotics, blood cultures frequently do not lead to reliable diagnoses. This provides an additional explanation for the disagreement between the two methods. Our results are in line with other studies showing that the difference between two diagnostic methodologies fluctuates from $8 \%$ to $80 \%$, depending on the materials used [11, 24-28]. This explains why the Septifast (Roche Diagnostics) kit is not yet recommended for clinical use in suspected sepsis [28]. Although the overlap between our method and blood 
cultures was $23.7 \%$ only in our study, the combination of the two methods revealed a diagnostic sensitivity of $57.7 \%$. This is a significant advantage over with a positive rate of $34 \%$ only and comparability with blood cultures of $8 \%$ [11]. Furthermore, our procedure takes only four hours, which is significantly shorter compared to $18 \mathrm{~h}$ required when using any available commercial kits in market [11].

Our detection methodology does not improve the diagnoses of samples with low levels of human DNA. This applies, for example, to CSF specimens. Pretreatment provides an improved DNA template for subsequent PCR and/or real-time PCR, and reaches a sensitivity of $10 \mathrm{CFU} / \mathrm{ml}$.

\section{Conclusion}

We established a simple optimized protocol for human DNA removal from blood sepsis samples. This method provides enriched bacterial DNA for subsequent PCRbased detection of bacterial DNA. With our established protocol, the downstream PCR assays can reach detection limits of $10 \mathrm{CFU} / \mathrm{ml}$ and, thus, enhance the positive rate of blood sepsis diagnoses.

\section{Additional file}

Additional file 1: Supplementary study data. (DOC 619 kb)

\section{Abbreviations}

BSI, bloodstream infection; CFU, Colony-forming unit; MCLB-1, mammalian cell lysis buffer; NAT, nucleic acid testing; PCR, polymerase chain reaction

\section{Acknowledgements}

We would like to acknowledge funding from the Vietnamese Ministry of Science and Technology (Grant: KC-10.43/11-15) for this study. Dr. Velavan acknowledges financial support for MTB from DAAD-Germany. The funders have no role in study design, data collection and analysis, decision to publish, and/or preparation of the manuscript.

\section{Availability of data and materials}

Data and supporting materials associated with this study will be shared upon request.

\section{Author contributions}

NTT, LHS and TPV designed and supervised the studies. MTB and DTQ conducted the experiments. TTTHien, TTTHuyen performed the sequencing analysis. $\mathrm{PQH}$, TVS, NTKP, TTL evaluated the clinical data and provided the clinical samples. NTT, LHS, HVT and TPV analysed the data and wrote the manuscript. CGM contributed to the revision of the draft and on proof reading. All authors read and approved the manuscript

\section{Competing interests}

The authors declare that they have no competing interests.

\section{Consent to publish}

All authors read the manuscript and have provided their consent to publish. All authors declare no conflict of interests.

\section{Ethics and consent to participate}

The study was submitted for regulatory approval to the institutional review board of the 108 hospital and was approved. Following submission, the Ethical Committee of the 108 Military Central Hospital, Hanoi has provided consent and ethical approval for the study was duly obtained. Informed written consent was obtained from all study patients and/or from their parents if the study participant was under 18 years of age.

\section{Author details}

${ }^{1}$ Department of Molecular Biology, 108 Military Central Hospital, Hanoi, Vietnam. ${ }^{2}$ Institute of Clinical Infectious Diseases, 108 Military Central Hospital, Hanoi, Vietnam. ${ }^{3}$ Department of Clinical Microbiology, 108 Military Central Hospital, Hanoi, Vietnam. ${ }^{4}$ Faculty of Infectious Diseases, Hai Phong Medical University, Hai Phong, Vietnam. ${ }^{5}$ Department of Gastroenterology, 108 Military Central Hospital, Hanoi, Vietnam. ${ }^{6}$ Institute of Tropical Medicine, University of Tübingen, Tübingen, Germany. ${ }^{7}$ Vietnamese - German Centre for Medical Research (VG-CARE), Hanoi, Vietnam.

Received: 8 December 2015 Accepted: 16 May 2016

Published online: 31 May 2016

\section{References}

1. Angus DC, van der Poll T. Severe sepsis and septic shock. N Engl J Med. 2013;369(9):840-51.

2. Liesenfeld O, Lehman L, Hunfeld KP, Kost G. Molecular diagnosis of sepsis: new aspects and recent developments. Eur J Microbiol Immunol. 2014;4(1):1-25.

3. Mancini N, Carletti S, Ghidoli N, Cichero P, Burioni R, Clementi M. The era of molecular and other non-culture-based methods in diagnosis of sepsis. Clin Microbiol Rev. 2010;23(1):235-51.

4. Espy MJ, Uhl JR, Sloan LM, Buckwalter SP, Jones MF, Vetter EA, Yao JD, Wengenack NL, Rosenblatt JE, Cockerill 3rd FR, et al. Real-time PCR in clinical microbiology: applications for routine laboratory testing. Clin Microbiol Rev. 2006;19(1):165-256.

5. Pletz MW, Wellinghausen N, Welte T. Will polymerase chain reaction (PCR)-based diagnostics improve outcome in septic patients? A clinical view. Intensive Care Med. 2011;37(7):1069-76.

6. Yagupsky P, Nolte FS. Quantitative aspects of septicemia. Clin Microbiol Rev. 1990;3(3):269-79.

7. Hansen WL, Bruggeman CA, Wolffs PF. Evaluation of new preanalysis sample treatment tools and DNA isolation protocols to improve bacterial pathogen detection in whole blood. J Clin Microbiol. 2009;47(8):2629-31.

8. Wang HY, Kim S, Kim J, Park SD, Uh Y, Lee H. Multiplex real-time PCR assay for rapid detection of methicillin-resistant staphylococci directly from positive blood cultures. J Clin Microbiol. 2014;52(6):1911-20.

9. Simonson AB, Servin JA, Skophammer RG, Herbold CW, Rivera MC, Lake JA. Decoding the genomic tree of life. Proc Natl Acad Sci U S A. 2005;102 Suppl 1:6608-13.

10. Rivera MC, Lake JA. The ring of life provides evidence for a genome fusion origin of eukaryotes. Nature. 2004;431(7005):152-5.

11. Bloos F, Sachse S, Kortgen A, Pletz MW, Lehmann M, Straube E, Riedemann NC Reinhart K, Bauer M. Evaluation of a polymerase chain reaction assay for pathogen detection in septic patients under routine condition: an observational study. PLoS One. 2012;7(9), e46003.

12. Peytavi R, Huletsky A, Belley-Montfort L, Martineau I. Concentration and Enrichment of Microbial Cells and Microbial Nucleic Acids from Bodily Fluids. In: Google Patents; 2011.

13. Loffler J, Hebart $H$, Schumacher $U$, Reitze $H$, Einsele $H$. Comparison of different methods for extraction of DNA of fungal pathogens from cultures and blood. J Clin Microbiol. 1997;35(12):3311-2.

14. Loonen AJ, Bos MP, van Meerbergen B, Neerken S, Catsburg A, Dobbelaer I, Penterman R, Maertens G, van de Wiel P, Savelkoul P, et al. Comparison of pathogen DNA isolation methods from large volumes of whole blood to improve molecular diagnosis of bloodstream infections. PLoS One. 2013; 8(8):e72349.

15. Ausubel FB, Kingston R, Moore D, Seidman JG, Smith J, Struhl K. Short Protocols in Molecular Biology. 3rd ed. 1995. p. 2-3.

16. Klaschik S, Lehmann LE, Raadts A, Hoeft A, Stuber F. Comparison of different decontamination methods for reagents to detect low concentrations of bacterial 16S DNA by real-time-PCR. Mol Biotechnol. 2002;22(3):231-42.

17. Dellinger RP, Levy MM, Carlet JM, Bion J, Parker MM, Jaeschke R, Reinhart K, Angus DC, Brun-Buisson C, Beale R, et al. Surviving Sepsis Campaign: international guidelines for management of severe sepsis and septic shock: 2008. Crit Care Med. 2008;36(1):296-327.

18. Murray PR, Baron EJ, Pfaller MA, Tenover FC, Yolken RH. Manual of Clinical Microbiology. Washington DC: ASM Press; 1999. 
19. Laboratory Methods for the Diagnosis of Meningitism. 2nd edition. WHO Manual; 2011.

20. Morrell M, Fraser VJ, Kollef MH. Delaying the empiric treatment of candida bloodstream infection until positive blood culture results are obtained: a potential risk factor for hospital mortality. Antimicrob Agents Chemother. 2005;49(9):3640-5.

21. Ibrahim EH, Sherman G, Ward S, Fraser VJ, Kollef MH. The influence of inadequate antimicrobial treatment of bloodstream infections on patient outcomes in the ICU setting. Chest. 2000;118(1):146-55.

22. Bergthold LA. The frayed alliance: business and health care in Massachusetts. J Health Polit Policy Law. 1990;15(4):915-8.

23. Guido M, Quattrocchi M, Zizza A, Pasanisi G, Pavone V, Lobreglio G, Gabutti G, De Donno A. Molecular approaches in the diagnosis of sepsis in neutropenic patients with haematological malignances. J Prev Med Hyg. 2012;53(2):104-8.

24. Chang SS, Hsieh WH, Liu TS, Lee SH, Wang CH, Chou HC, Yeo YH, Tseng CP, Lee CC. Multiplex PCR system for rapid detection of pathogens in patients with presumed sepsis - a systemic review and meta-analysis. PLoS One. 2013;8(5), e62323.

25. Casalta JP, Gouriet F, Roux V, Thuny F, Habib G, Raoult D. Evaluation of the LightCycler SeptiFast test in the rapid etiologic diagnostic of infectious endocarditis. Eur J Clin Microbiol Infect Dis. 2009;28(6):569-73.

26. Lodes U, Bohmeier B, Lippert H, Konig B, Meyer F. PCR-based rapid sepsis diagnosis effectively guides clinical treatment in patients with new onset of SIRS. Langenbecks Arch Surg. 2012;397(3):447-55.

27. Wellinghausen N, Kochem AJ, Disque C, Muhl H, Gebert S, Winter J, Matten J, Sakka SG. Diagnosis of bacteremia in whole-blood samples by use of a commercial universal 165 rRNA gene-based PCR and sequence analysis. J Clin Microbiol. 2009;47(9):2759-65.

28. Dark P, Blackwood B, Gates S, McAuley D, Perkins GD, McMullan R, Wilson C, Graham D, Timms K, Warhurst G. Accuracy of LightCycler((R)) SeptiFast for the detection and identification of pathogens in the blood of patients with suspected sepsis: a systematic review and meta-analysis. Intensive Care Med. 2015:41(1):21-33.

\section{Submit your next manuscript to BioMed Central and we will help you at every step:}

- We accept pre-submission inquiries

- Our selector tool helps you to find the most relevant journal

- We provide round the clock customer support

- Convenient online submission

- Thorough peer review

- Inclusion in PubMed and all major indexing services

- Maximum visibility for your research

Submit your manuscript at www.biomedcentral.com/submit 